\title{
Sporothrix Schenckii: a rare fungal lesion mimicking common granulomas, a case report
}

\author{
Niranjanakesav ${ }^{1}$, Sathiya Bama ${ }^{2 *}$, Radhakrishnan ${ }^{3}$, Arbind Kumar ${ }^{4}$
}

\begin{abstract}
${ }^{1}$ MBBS Student, Virchow Biopsy Centre, Thanjavur, Tamil Nadu, India
${ }^{2}$ Department of Pathology, IRT Perundurai Medical College and Hospitals (IRT-MPCH), Perundurai, Tamil Nadu, India

${ }^{3}$ Department of Pathology, Virchow Biopsy Centre, Thanjavur, Tamil Nadu, India

${ }^{4}$ Department of Pharmacology, IRT Perundurai Medical College and Hospitals (IRT-MPCH), Perundurai, Tamil Nadu, India
\end{abstract}

Received: 04 June 2018

Accepted: 16 July 2018

*Correspondence:

Dr. Sathiya Bama,

E-mail: sathiyabamad@gmail.com

Copyright: ( $)$ the author(s), publisher and licensee Medip Academy. This is an open-access article distributed under the terms of the Creative Commons Attribution Non-Commercial License, which permits unrestricted non-commercial use, distribution, and reproduction in any medium, provided the original work is properly cited.

\begin{abstract}
The patient, a 35-year-old lady, reported for a deeply fixed skin swelling in the leg. The proper diagnosis is likely to be missed if attention is concentrated only on the granulomas. Though diagnosis is possible through Hand E stains, accurate identification of the characteristic morphological features of this fungus is essential for proper diagnosis and treatment. Contrary to the usually held view, in this patient, unusually large number of fungal elements with varying morphology is noticed in Hand E sections.
\end{abstract}

Keywords: Fungal granuloma, Sporothrix, With micro abscesses

\section{INTRODUCTION}

Sporothrix schenckii is a rare dimorphic fungus; transmitted by direct inoculation as in gardeners handling rose plants, or farmers hauling hay etc or veterinarians treating pet animals. ${ }^{1}$

It starts as a small indurated lesion which ulcerated later and becomes discolored with extensive crusting and boils. Though reported also as disseminated disease, systemic involvement is rare. If extensive, due to much destruction locally it mimicks a tumour as in the case under discussion. ${ }^{2}$

As it is likely to be mistaken clinically and pathologically, for many varied lesions with granulomatous features, it is imperative to diagnose it accurately and treat it effectively by simple means.

\section{CASE REPORT}

The complaint for which this 35-year-old woman sought consultation was for discoloured nodular swelling of skin over the medial aspect of her left leg. According to her, it was chronic and slowly increasing in size, On examination, the margins are ill defined and the swelling was surrounded by oedematous discoloured skin.

When it was excised surgically it measured $2.5 \mathrm{~cm} \times 3.0$ $\mathrm{cm} \times 2.0 \mathrm{~cm}$ in dimension. The lesion was soft, the upper margin was well defined while lower margin was deep seated and extended into underlying fat. The entire dermis was replaced by nodules of granulomas: many of which were coalascent. Necrotic abscesses were seen more deeply. Giant cells; a dominating feature in these nodules are large in size; larger than those seen in giant cell tumors. Epithelioid aggregates were minimal. They 
were encircled by diffuse infiltrates of chronic inflammatory cells including many eosinophils.

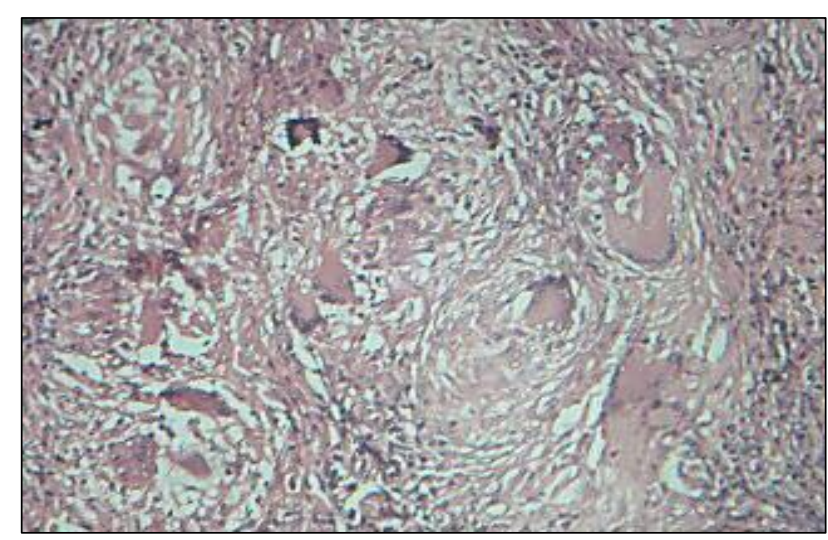

Figure 1: Granulomatous nodule with micro abscess in the center.

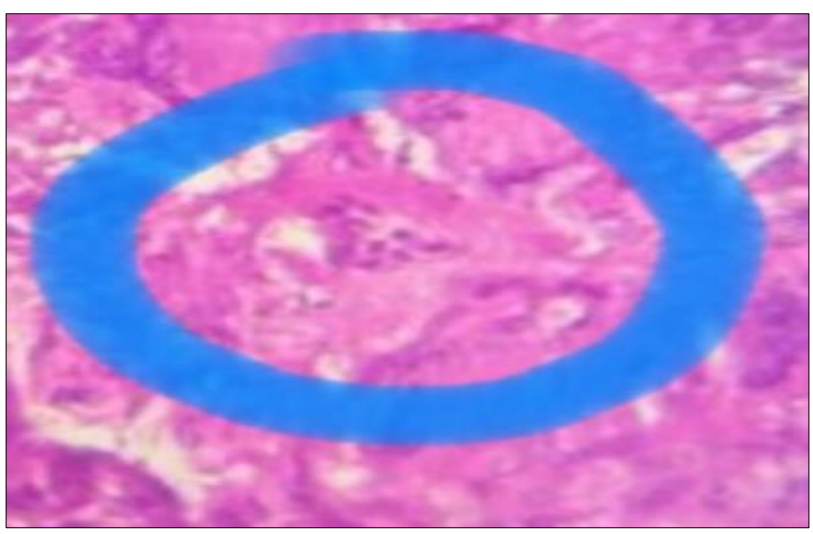

Figure 2: Spores (with a circle around them).

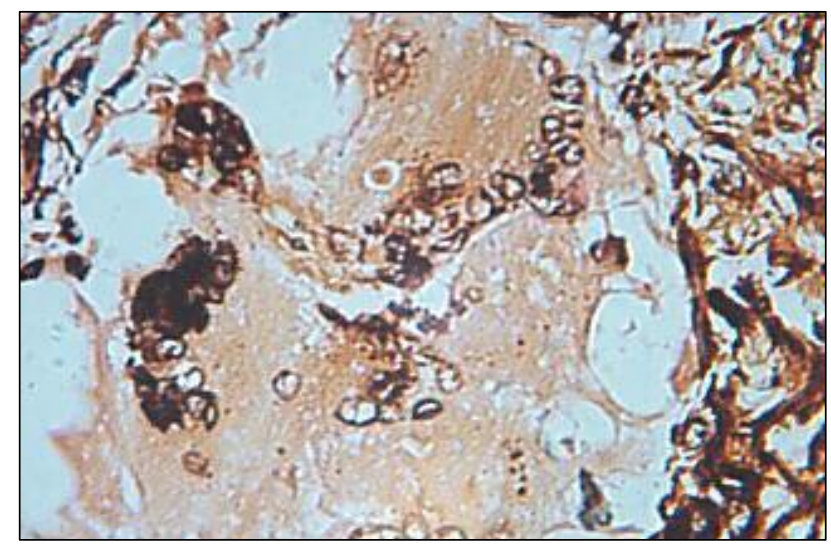

Figure 3: Characteristic fungal elements G. M. S. Stain.

In the abscesses, as well as in giant cells numerous rounded spores, 2 to 5 microns in size could be seen; many of which exhibiting also budding forms or tear drop forms. Fractured asteroid bodies were noticed in a diffuse manner. Microabscesses were distributed as a part of granuloma or separately; Spores could be identified well in Hand E sections unusually and are confirmed by G.M.S. fungal stains.

\section{DISCUSSION}

The first clue as to the nature of this tumour is its granulomatous nature; mixed with microabscesses occurring as part of granulomas or separately as abscesses with necrosis. According to Lamps $\mathrm{L}$ granulomatous inflammation can be divided into:

a) Epithelioid granulomas with or without necrosis,

b) Lipogranulomas,

c) Microgranulomas,

d) Fibrin ring granulomas as in Q fever,

e) Foamy macrophagic aggregated as in whipples

f) Granulomas with prominent suppurative inflammation,

g) Stelate abscesses associated with Palisading granulomas. ${ }^{3}$

It is obvious that in this patient the granulomas belong to (f) category as listed above and as emphasized by Chandler fulfilling all the essential features encountered in this fungal lesion. ${ }^{4}$ There is no lymphatic spread as in $25 \%$ of reported cases G.M.S fungal stain confirms the diagnosis; as it reveals the round or oval yeast forms, 2 to 4 microns in size, or budding or tear drop or cigar shaped features of this fungus better. ${ }^{5}$ They are localized usually in giant cells or extracellularly.

Mycelial forms are not seen in tissues; they are present only in culture. The extensive nature of the granulomas with abscesses involving even subcutancous fat may be related to lack of immunological resistance. The line of treatment is simple like topical application of Potassium Iodide and differs vastly from the usual treatment granulomatous diseases. ${ }^{1}$

\section{CONCLUSION}

Sporothrix Schenckii a rare fungal infection often mistaken for other granulomatous inflammation. The classical morphology of multiple suppurative granulomas with the help of special stain for fungus -GMS confirm the diagnosis. As the line of treatment differ from usual granulomatous inflammation.

Funding: No funding sources

Conflict of interest: None declared

Ethical approval: Not required

\section{REFERENCES}

1. Milner, Percora, Solomon, Soong. Infectious diseases (Diagnostic pathology series). Elsevier; 2015;3:56-59.

2. Zhang Y, Pyla V. Cancer like lesions in a patient with sporotrichosis. Int J Dermatol. 2014;53(4):e3112 . 
3. Lamps L. Hepatic granulomas, with an emphasis on infectious causes. Adv Anat Path. 2008:(6):309-17.

4. Chandler, Kaplan, Ajello. Histopathology of mycotic diseases. Wolfe Medical Publications Ltd; 1980:112115.

5. Binford CH, Dooley TR. Sporotrichosis. In: Binford $\mathrm{CH}$, Connor DH. Pathology of tropical and extraordinary diseases. Armed Forces of Institute of Pathology; 1976:574-577.

Cite this article as: Niranjanakesav, Bama $S$,

Radhakrishnan, Kumar A. Sporothrix Schenckii: a rare fungal lesion mimicking common granulomas, a case report. Int J Reprod Contracept Obstet Gynecol 2018;7:3432-4. 